\title{
NATURAL HYBRIDS OF TWO SPECIES OF ARCTO- STAPHYLOS IN THE YOSEMITE REGION OF CALIFORNIA
}

\author{
THEODOSIUS DOBZHANSKY \\ Columbio University, New York
}

Received 4.iii.52

\section{INTRODUCTION}

THE purpose of the present note is to record a striking case of natural hybridisation of two species of manzanita bushes, Arctostaphylos mariposa Dudley and $A$. patula Greene, in and near Yosemite National Park, California. The weakness of this case, first reported by Epling (1947) is that the available data are derived from field observations in only a fraction of the total distribution area of the species, and are unsupported by experimental evidence. On the other hand, the case is remarkably clear and instructive since the environmental relationships of the parental species and of the hybrids are readily discernible.

\section{THE PARENTS AND THE HYBRIDS}

A. mariposa and $A$. patula are common and conspicuous members of the preclimax vegetation of the hillslopes in the Transition and in the lower portion of the Canadian life zones of the Sierra Nevada of California. In places they are abundant enough to form dense thickets of tall bushes or small trees on exposed slopes. They do not, however, grow on meadows and become depressed when forest shade develops above them. A. mariposa occurs at lower elevations than A. patula. According to Hall and Hall (IgI2) the former species occurs up to the elevation of 6000 feet, and the latter from 4500 to 9000 feet. In the region where the observations reported below have been made, $A$. mariposa extends from about 2500 to 6000 feet ; and $A$. patula from approximately 4500 to 8000 feet above sea level. Taken at face value, these figures would indicate that the zone in which both species occur is about I50o vertical feet. In reality it is usually narrower, because on slopes with southern exposure $A$. mariposa grows higher than on northern exposures. Conversely, the lower limit of A. patula extends lower on northern exposures than on southern. The soil drainage likewise influences the altitudinal limits of the species, rocky slopes being more accessible to $A$. mariposa than to $A$. patula. For these reasons, the altitudinal limits of the zone of overlap vary greatly from place to place. Occasionally the replacement of the species occurs without any overlap at all. This has been observed along a trail leading from the Rancheria Mountain to Hetch-Hetchy, in Yosemite Park. This trail first descends a mountainside with a north-eastern exposure, then emerges on a lower slope 
with a southern exposure. Only $A$. patula has been seen on the north-east, only $A$. mariposa on the southern slope.

Morphologically the two species differ so clearly that they can be identified without hesitation even at a distance of one hundred feet or more (Jepson, 1923-25; Epling, 1947). A. mariposa has white-glaucous foliage which appears greenish-grey; $A$. patula, bright green glabrous leaves. The former species is generally taller, more erect, and has the branchlets, the inflorescence, and the berries densely covered with glandular pubescence which makes them very sticky to touch. $A$. patula is usually lower, frequently semi-prostrate, and its inflorescent is only minutely pubescent, the berries large, glabrous or nearly so, never sticky. The leaves of $A$. mariposa are on the average smaller (mostly 2 to $4 \mathrm{~cm}$. long) than the $A$. patula $(3$ to $5 \mathrm{~cm}$. and even more). The stems of $A$. patula form a "burl ", i.e. an irregularly globose body, under the soil surface, which crown-sprouts after fire. A. mariposa does not have this property.

The hybrid bushes are on the whole intermediate between the parents, but somewhat closer to $A$. patula in the conspicuous traits. Their leaves are bright green, slightly glaucous and therefore not glossy. The leaf size is only slightly smaller than in $A$. patula. The manner of growth approaches that in $A$. mariposa rather than that in $A$. patula. The inflorescence is moderately pubescent but not glandular and not sticky. The berries are almost glabrous, like in A. patula. The variation in the hybrids is not any greater than it is in the parental species, and there is no overlapping at all, making the hybrids a morphological array which can be separated without hesitation from those of the parents (Epling, 1947).

\section{A SAMPLE TRANSECT}

Observations were made on the relative frequencies of the individuals of the two species and of the hybrids in several localities in the Yosemite region. Usually a trail or a road was selected leading from the lower elevations where only $A$. mariposa is found to the higher areas where only $A$. patula is encountered. The bushes on either side of the trail were classified as to species. On two such transects counts were made of the numbers of bushes of the three kinds growing within five metres on either side of the trail. The trail was subdivided into sections roo paces long, the section boundaries marked, and the bushes counted and recorded. The direction of each section of the trail was determined with the aid of a compass, and a rough map was prepared. The elevation above the sea level of the different parts of the trail was determined with the aid of an aircraft altimeter. Notes were made on the vegetation in each section, as well as on the characteristics of the soil, slope, etc.

One of the transects is reproduced in fig. I. The individuals of $A$. patula are marked by black circles, A. mariposa with white ones, 
and hybrids with half black and half white. The trail leads from Mather to the Cottonwood Meadow in the Yosemite Park. The counts were started at the elevation of 4800 feet and finished at 5500 feet. In all, 745 A. mariposa, $\mathrm{I} 66 \mathrm{~A}$. patula, and 37 hybrids were counted. On this particular transect very few young bushes were found, a majority being mature fruiting individuals. Below 4800 feet many A. mariposa and a single hybrid bush were noted, and above 5500 feet numerous $A$. patula and also a single hybrid bush occur along the trail. The part of the trail along which counts were made thus covers the transition between the distribution areas of the two species.

Section I of the transect (fig. I) abuts a flat densely overgrown with young yellow pines (Pinus ponderosa Dougl.) and incense cedars (Libocedrus decurrens Ferr.). Sections I-4 climb up a slope of a hill, mostly exposed to the sun, but with few scattered yellow pines. Here are found 192 bushes of $A$. mariposa, no $A$. patula, and 4 hybrids. Sections 5-7 cover fairly flat ground with deeper soil and scattered oaks (Quercus Kellogii Newb.), cedars and pines. There 6 hybrids and $\operatorname{sog} A$. mariposa are found. Sections 8 and 9, elevation 4900 feet, begin to climb up a fairly gentle slope with scattered oaks, pines and cedars. There another eighthybrids are recorded. Sections Io

Fig. 1.-A sample transect of the altitudinal zone in which Arctostaphylos mariposa (open circles), A. patula (solid black circles), and their hybrids (blackand-white circles) occur. The numerals indicate the numbered sections of the transects and the elevations, in feet above the sea level.

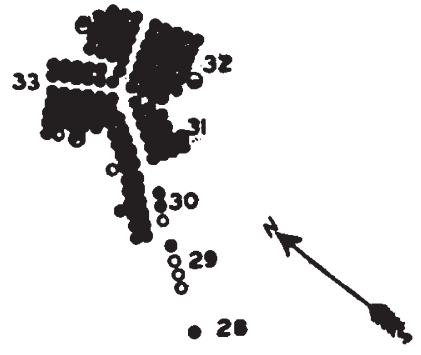

- 27

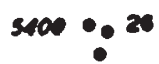

sors

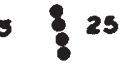

024
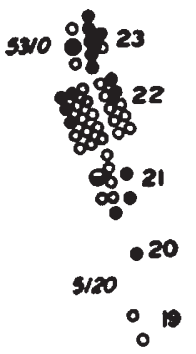

savo is

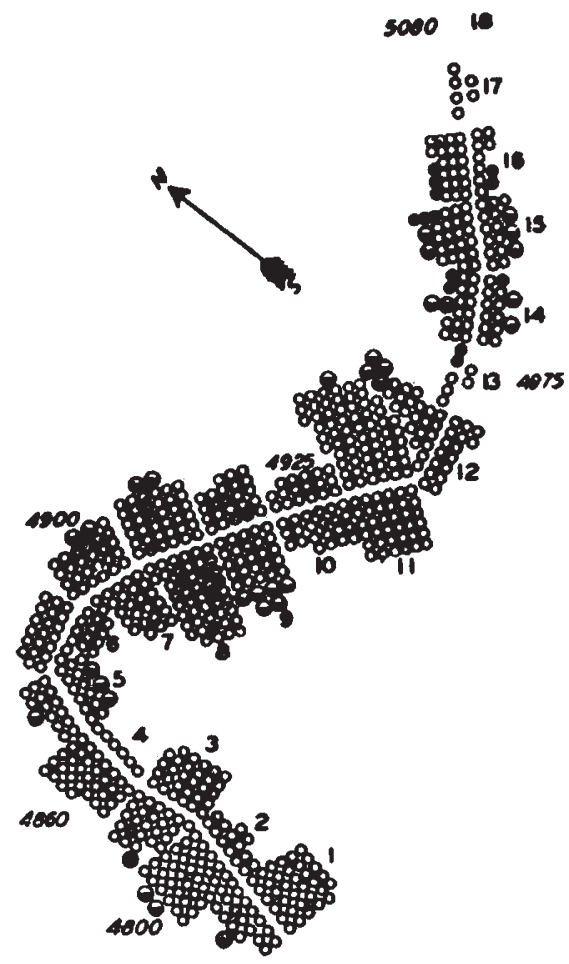


and I I are on a much steeper and rocky slope exposed to the south and devoid of shade. Numerous $A$. mariposa grow on this slope, but the single hybrid is found close to the boundary of Section I 2, where the conditions change. The absence of hybrids in Sections Io and I I is probably significant-they are less well adapted than $A$. mariposa to grow on hot and exposed slopes at this elevation.

Sections 12 to 16 enter the mouth of a canyon, with some large pines, cedars and oaks, particularly to the right of the trail, and with less rocky soil. There I $29 A$. mariposa, I 3 hybrids, and the first I 3 bushes of $A$. patula have been counted. Both the hybrids and $A$. patula grow in relatively flat, more protected locations with some shade from the larger trees. Sections I 7 to 20 are unfavourable for Arctostaphylos, being shaded by a dense growth of yellow and sugar pines (Pinus Lambertiana Dougl.), cedar, white fir (Abies concolor Linde), oak and Douglas fir (Pseudotsuga taxifolia Lamb.). The few $A$. mariposa and the single $A$. patula are depressed individuals. Sections 2 I to 24 are climbing up along the bottom of a fairly steep-walled canyon with a small impermanent stream at the bottom. The slope to the right (south-east) of the trail is much more densely wooded than that on the left. Almost all Arctostaphylos bushes are growing on the left slope of the canyon (although not necessarily to the left of the trail). Both species and hybrids are found, with $A$. patula and the hybrids clearly selecting the less dry and more protected situations.

Sections 25-29 are in the head of the canyon, where the sides are less high and less steep. There is much forest shade, the Arctostaphylos bushes being not numerous near the trail but more abundant higher up on the left slope. Examination of these bushes (not entered in fig. I) discloses that the upper and exposed parts of the slope have chiefly $A$. mariposa and a few hybrids, while along the trail $A$. patula predominates. Finally, Sections $30-33$ are on a small plateau at the elevation of approximately 5500 feet. On this plateau, and higher up on the Sierra slope, $A$. patula is clearly the predominant species. Some hybrids, and the last $A$. mariposa, occur, however, on this plateau.

\section{OTHER TRANSECTS}

Conditions similar to the ones described above have been observed on other transects as well. Within the zone of the overlap, A. mariposa grows relatively more frequently in hot, exposed, or rocky situations, while $A$. patula and the hybrids occur in more protected, less arid places, frequently with some shade. And no matter how wide or narrow is the zone of the overlap, always a decided majority of the bushes belong to the two parental species, with hybrids in a minority. Along the road from Mather to Aspen Valley the zone of the overlap extends from the elevation of about 4900 to 6000 feet and for about three miles horizontally. Counts were made of bushes within five metres on either side of the road. A. patula was represented by 1051 
individuals, $A$. mariposa by I Io, and only 27 hybrids were found. The predominance of $A$. patula on this transect is due to the fact that its lower part has too much shade to support numerous Arctostaphylos. A few miles away from there, on a margin of Ackerson Meadow which was logged and partly burned in 1946, numerous young bushes are found. Our counts showed that less than I per cent. among them are hybrids, and about 8 o per cent. are $A$. mariposa. It would be interesting to compare the relative frequencies of the pure species and the hybrids in a decade or a larger time interval, since it is possible that the hybrids. may be eliminated at rates greater than the pure species.

\section{CONCLUSIONS}

$A$. mariposa and $A$. patula are two Mendelian populations which are adapted to occupy related but distinctly different adaptive niches. The former is superior under the more arid conditions of the lower, and the latter under the less arid ones of the intermediate elevations, in the Sierra Nevada of California. The two populations must clearly be regarded as specifically rather than only racially distinct. This is because the gene exchange between them is clearly not effective enough to erase the barriers to further gene flow. Their genetic systems are almost completely closed. This fact is reflected on the morphological surface to permit classifying the individuals observed in three discrete arrays-that of $A$. mariposa, of $A$. patula, and that of the hybrids. The first two arrays are much larger than the third one, even in the zone of the geographic and environmental overlap where the hybrids occur.

It should be stressed that the hybrids do not seem to be sterile. At any rate, the hybrid bushes produce crops of berries just as abundantly as do the parental species. The seeds are visibly normal, but no germination experiments have been made. This raises the question of what prevents the spread of the hybrids and the swamping of the species boundary, at least in the zor'e of the distributional overlap, which would degrade the species to 1 aces. A great majority of the hybrids are, as stated above, a discrete array which is not noticeably more variable than the parental species. This suggests that they are the $F_{1}$ hybrid generation, although one cannot exclude the possibility that a small minority of them may be $F_{2}$ or backcross products. Bushes which, on morphological grounds, appear to be backcross individuals are rare, although they are found. In the part of the Yosemite region in which the observations were made, eight bushes have been noted which, with varying degrees of assurance, can be described as intermediates between the $F_{1}$ hybrids and the parents. Of these, six suggest backcrosses to $A$. mariposa and two to $A$. patula. Four are fairly large, and they have been observed to produce berries in several successive seasons.

Efforts have been made to detect the possible introgression of 
the genes of $A$. mariposa into $A$. patula, and vice versa, particularly in the zone of the overlap. Although the writer does not claim an " ability to spot introgression in the field, sometimes almost instantly and frequently in organisms with which one was unfamiliar" (Anderson, 1951), the populations of both species were inspected within and outside the zone of the overlap. Such inspection shows, to an increasing degree as one becomes more familiar with the plants, the existence of local, intercolonial variations in all sorts of traits. How much of this variation, is genotypic and how much purely environmental is, of course, impossible to tell. What is important for our purpose is that no indication was observed of mutual approximation of the species in the zone of the overlap, except, possibly, that $A$. patula tends to be more erect than it is further up the Sierran slope. The erectness is a trait characteristic of $A$. mariposa.

It is quite possible that a narrow channel for gene exchange between the species is preserved. Morphological observation could not exclude this possibility entirely, especially since backcrosses of the hybrids to $A$. patula might produce progenies that would be difficult to recognise. The important fact is that the gene exchange, if it occurs, does not furnish in the Arctostaphylos case genetic building blocks for adaptive modification of local populations. Since both $A$. mariposa and $A$. patula come up most abundantly on disturbed soils after burning or logging the forest, human activities have doubtless increased the sizes of the populations of both species as well as opportunities for species crosses. It is, however, unlikely that no hybrids at all were found until men came. If so, the absence of clear introgression effects suggests that the two species are coherent genetic systems which form a reasonably fit $F_{1}$ hybrid, but which suffer a breakdown in $\mathrm{F}_{2}$ and in backcrosses, with natural selection eliminating most or all recombination products. Formation of some viable and fertile hybrids between species in nature does not necessarily erase the reproductive isolation which keeps their genetic systems separate.

\section{SUMMARY}

Two species of manzanita bushes, Arctostaphylos mariposa and A. patula, form some natural hybrids. The former species occurs at lower elevations and in drier and more exposed sites than the latter, but in a fairly narrow altitudinal belt the two occur together. The hybrids, which are mostly $F_{1}$ and much less often $F_{2}$ or backcross products, never form more than ro per cent. of the population of the region in or near which both parental species also occur ( $c f$. fig. I). In that region, the parental species and the hybrids tend to occupy somewhat different habitats. There are no indications of extensive introgression of genes of $A$. mariposa into $A$. patula or vice versa. It is suggested that an important isolating mechanism which keeps the 
gene pools of these species closed systems is adaptive inferiority of most products of gene recombination.

Acknowledgments.-Thanks are due to Professor G. L. Stebbins, who first called the attention of the writer to the Arctostaphylos situation in 1945; to Professor C. Epling in co-operation with whom the first observations were made in 1945 ; to Miss Sophie Dobzhansky, who, in $195 \mathrm{I}$, shared the work of making the counts of the plants and preparing the maps of the transects; and to Dr Jens Clausen and his colleagues of the Division of Plant Biology of the Carnegie Institution of Washington, whose hospitality at Mather furnished the opportunity to carry out the observations here reported.

\section{REFERENCES}

ANDERSON, E. I951. Concordant versus discordant variation in relation to introgression. Evolution, 5, 133-141.

EPLING, C. 1947. Actual and potential gene flow in natural populations. Amer. Natur., 8I, I 04-I I 3 .

hall, H. M., AND Hall, c. c. igi 2. A rosemite Flora. P. Elder Company, San Francisco.

Jepson, w. L. 1923-25. A Manual of the Flowering Plants of California. Assoc. Students, Berkeley, California. 